\title{
Putting theory into practice: the creation of REALs in the context of today's universities
}

\author{
Sally Ann Kitts* and John T. Hancock** \\ *Department of Hispanic, Portuguese and Latin American Studies, University of \\ Bristol, email: s.a.kitt@@bristol.ac.uk \\ **Department of Biological and Biomedical Sciences, University of the West of \\ England, Bristol
}

Rich Environments for Active Learning (REALs), as described by R. Scott Grabinger and Joanna Dunlap, are comprehensive educational systems based on constructivist principles that present an intellectual and practical challenge to university lecturers. As teachers and researchers, academics are concerned with improving the learning potential of teaching strategies and, to this end, the theory of the REAL provides inspiration and ideas based on sound theoretical principles. Yet in the context of the current pressured climate, having the time and resources to put such an extensive. theory into practice can seem little more than a pipe-dream. It is argued that using a computer-based application such as the Hypermedia Learning Tutorials (HLTs) as the heart of a REAL allows lecturers to take positive steps towards the creation of comprehensive, flexible, integrated learning environments. The concept of the HLT is discussed and a practical application in the field of advanced second-language acquisition is described. Based on conceptual analysis and the results of preliminary student evaluation, it is argued that the HLT encompasses both in theory and in practice the chief qualities of REALs and can form the basis for their creation in a wide variety of disciplines.

\section{Introduction}

Bringing together theory and practice in the context of university teaching is no mean feat. On the one hand, lecturers are challenged and motivated intellectually by the theoretical arguments in the field of education of thinkers such as Grabinger and Dunlap, who have written extensively about comprehensive constructivist learning communities which they term Rich Environments for Active Learning (REALs) (Grabinger and Dunlap, 1995; Grabinger and Dunlap, 1998; Grabinger, Dunlap and Duffield, 1997). Yet, on the other hand, they are also challenged and demotivated on a day-to-day basis with the practicalities of teaching increasing numbers of 
students with a decreasing unit of resource in institutions where competition for funding is fierce and where there is pressure from external reviews of research and teaching performance.

Grabinger and Dunlap (1995) are careful to point out that REALs, in the full sense of the acronym, are large-scale holistic communities encompassing all aspects of the teaching and learning experience, and reject 'delivery technologies', 'computer microworlds' and 'computerbased applications' as REALs. The practical task of creating such complete, all-encompassing learning systems can seem daunting, even impossible given the pressures faced by lecturers in the present higher education climate. The present paper will argue that, far from being highly limited and inflexible, as Grabinger and Dunlap suggest, when fully integrated into the teaching programme, computer-based applications like the Hypermedia Learning Tutorials (HLTs) discussed below can lie at the heart of flexible learning environments.

The paper will begin with a discussion of the concept of the REAL as a theoretical constructivist approach to teaching and learning. After initial consideration of the concept of an HLT, theory will be linked to practice in exploring the application of the concept to the area of advanced second-language acquisition with the creation and integration of the HLTs for Spanish, Caminos a la expresividad (Pathways to Expressivity). The final part of the paper will show how the HLT, in spite of its essentially computer-based format, encompasses both in theory and in practice many of the qualities set out in the theory of REALs.

\section{REALs: learning communities founded on constructivist principles}

Constructivism is a term describing a theory of learning which grew from a theory about knowledge, developed by Piaget. His work on cognition from the 1920 s onwards eschewed the idea that knowledge has an independent reality which will one day be attained. Instead he emphasized the role of cognitive subjects actively involved in a continual process of building their own conceptual representations of the world: 'knowledge proceeds neither solely from the experience of objects nor from an innate programming performed in the subject but from successive constructions' (Piaget, 1977, p. v).

This view of knowledge as constructed by individuals from their experiences led naturally to a reconsideration of the way in which people learn and this in turn to the way in which they are taught. Learning is seen as a dynamic process with the emphasis on the learner rather than the knowledge to be acquired. Learners will encounter new experiences and ideas from idiosyncratic perspectives and will either adapt their personal constructs (schemas) or create new ones within the overall construct which is their knowledge about the world. With the rejection of the Lockean view of the mind as a tabula rasa on to which the teacher aims to inscribe a fixed body of facts called knowledge, the focus is transferred on to the constructive mind and the role of the teacher is to facilitate the process of the creation, adaptation and refinement of schemas (Desforges, 1997). In order to fulfil this facilitative function, teachers have to make use of strategies that present new information and ideas about the world in such a way as to enable, encourage and support their students in the process of constructing and modifying their knowledge, a process which will be different according to the experience of each individual.

REALs are comprehensive instructional systems that 'provide learning activities that engage the students in a continuous collaborative process of building and reshaping understanding as a 
natural consequence of their experiences and interactions within learning environments that authentically reflect the world around them' (Grabinger and Dunlap, 1995, p. 5). Premised on constructivist principles, they promote an integrative approach to teaching that provides students with appropriate and varied learning strategies that enable them to take control of and responsibility for their own learning in a fully supportive, contextualized and meaningful environment.

\section{The concept of the Hypermedia Learning Tutorial}

The term Hypermedia Learning Tutorial is used to describe a synthetic approach to student learning that centres on a highly flexible and adaptable computer application, created using Asymetrix Toolbook. The concept of the HLT is applicable to a wide variety of disciplines: the central computer-based learning application is fully authorable and the constructivist integrative approach can be adapted and tailored to subjects as wide-ranging as molecular cell biology or advanced second-language acquisition, two examples currently being developed at the University of the West of England, Bristol, and the University of Bristol respectively.

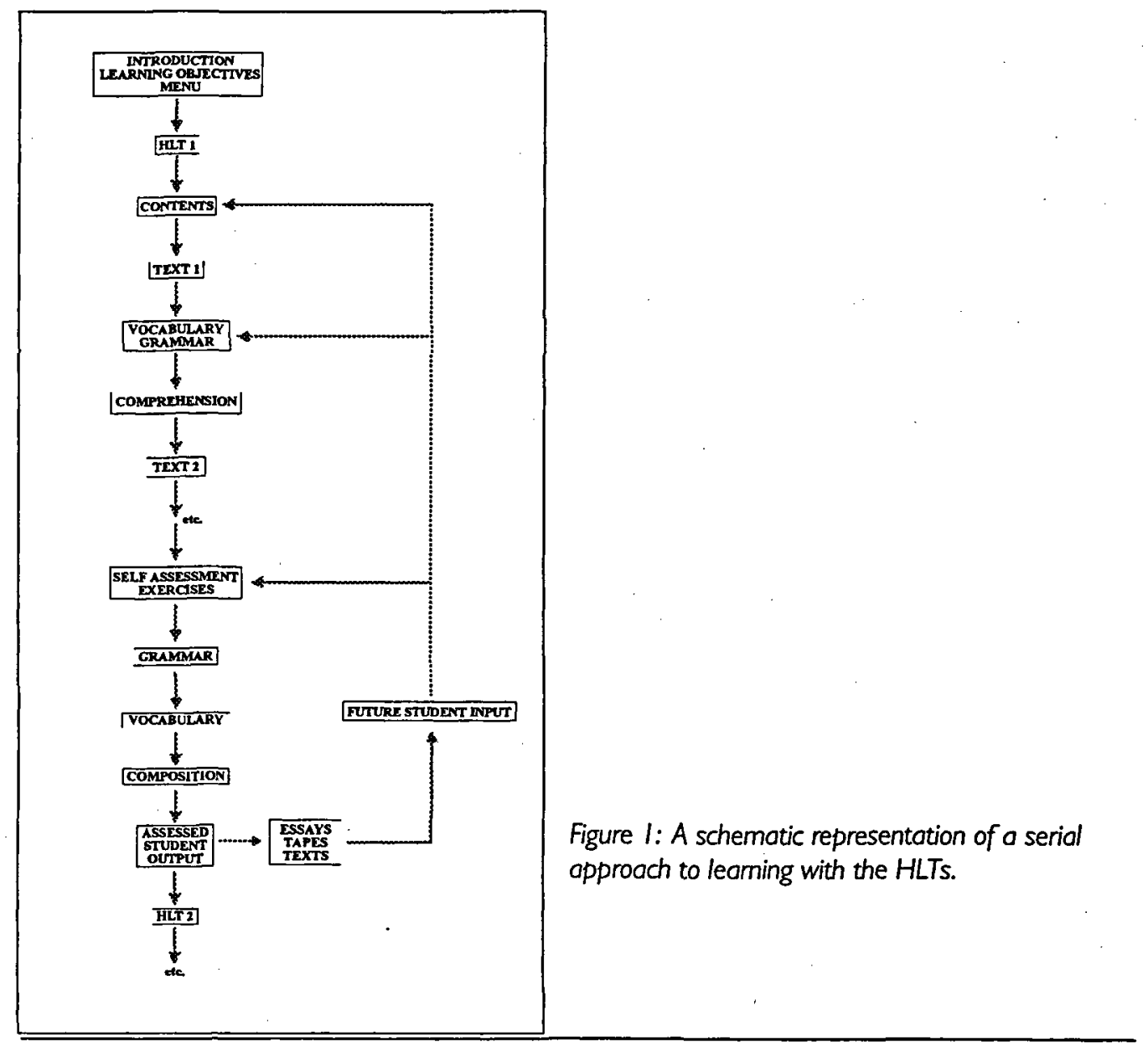




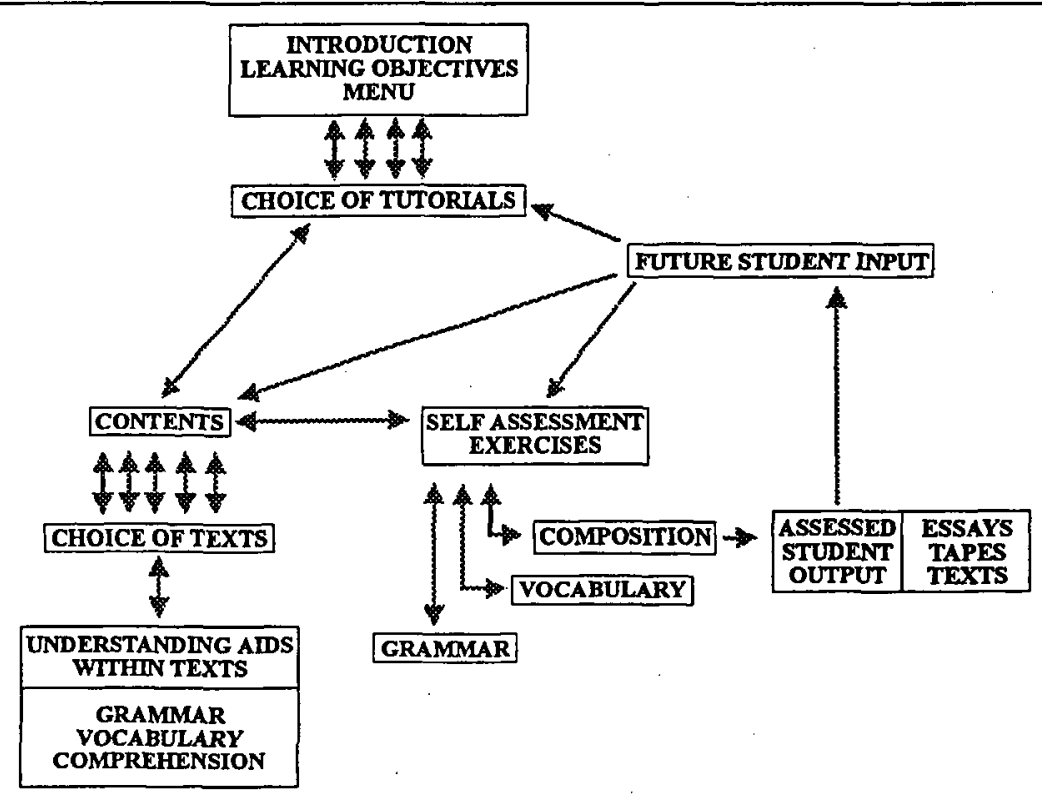

Figure 2: A schematic representation of a holistic approach to learning with the HLTs.

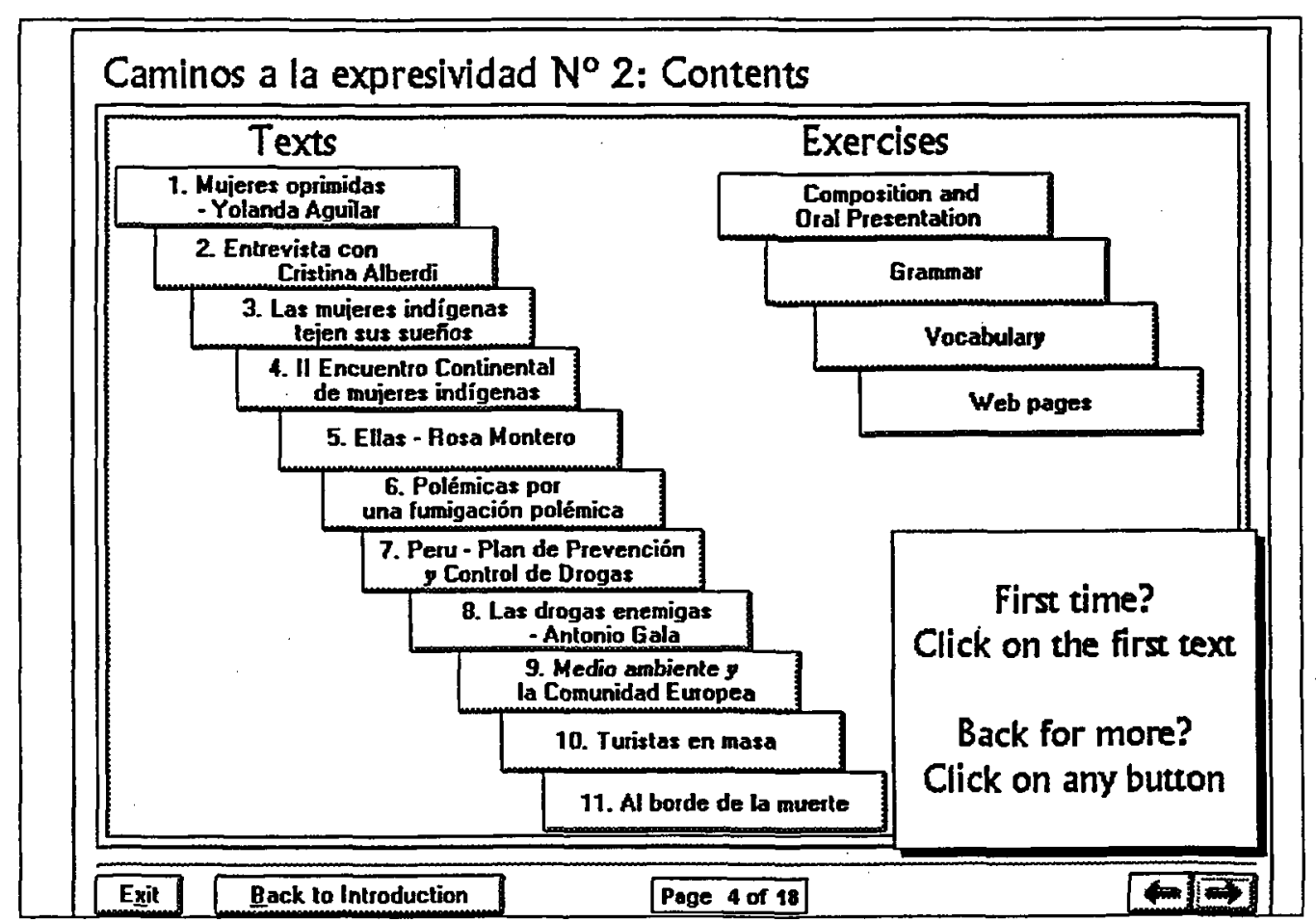

Figure 3: The clickable contents overview from HLT 2 in the Caminos a la expresividad series. 


\section{Text 3: Nación, Nacionalidades, Nacionalismo (varios)}

¿Qúe es una nación? ¿Qué significa ser nacionalista? Aqui y en las páginas que siguen hay una serie de textos sobre este $y$ otros asuntos relacionados con el tema de la España de las naciones. Ofrecen definiciones y opiniones, ideas y propuestas, clarificaciones $y$ deseos para el futuro.

Algunas definiciones de las palabras nación, nacional, nacionalidad, y nacionalismo, según el Diccionario General nustrado de la Lengua Española

Nación.

1. Sociedad natural de hombres, a los que la unidad de territorio, de orígen e historia, de cultura, de costumbres o de idioma, inclina a la comunidad de vida y crea la conciencia de un destino comin

2. Conjunto de habitantes de un pais regido por el mismo gobiemo.

3. Territorio de ese mismo pais.

4. En Bolivia, extranjero dicho de personas.

Sinónimo: pueblo

Figure 4: A typical HLT screen from Caminos a la expresividad showing hotwords, audio buttons, navigation buttons, notepad facility and button linking to self-assessment comprehension exercise.

HLTs are completely student-centred learning environments that place students firmly in control of exactly what, how much and how they learn. Using HLTs students focus on and explore the resources and support they need as individuals. They access the material in a form that suits their own particular learning preferences, an important aspect to consider if an application is to be successful (Jones, Jacobs and Brown, 1997). The tutorials are constructed so as to offer both a guided 'serial' approach (Figure 1) and an open, exploratory or 'holistic' approach (Figure 2), or a mixture of the two. The terms 'serial' and 'holistic' were first used in this context by Pask (1976).

The tutorials are made available on a 24-hour open-access basis and in that sense students can make as much or as little use of them as they wish, whenever they wish. However, the tutorials are also fully integrated into the structure of existing teaching programmes using a variety of links which serve both to encourage students to use them and to extend the learning potential of both the HLTs themselves and the current teaching programme. This approach is consistent with the acknowledgement that student motivation and a successful integration strategy are key elements of a successful implementation programme (Stoner, 1997; Harvey and Mogey, 1997).

HLTs are thematic and centre on a wide selection of meaningful material including straightforward written texts, audio/video recordings, animations, pictures and diagrams (hereafter referred to simply as texts). Progress through the different texts can be linear, using the basic forward and backwards navigation buttons at the bottom of the screen, or exploratory via a clickable contents map or overview (Figure 3). 
Key elements of the texts are hyperlinked to provide instant clarifications or examples should the student wish to click on them. In the case of audio/video recordings this is effected via accompanying transcriptions. Each text is linked via a screen button to an interactive comprehension exercise which enables students to assess their understanding of the key concepts contained within it, with instant feedback and a score provided (Figure 4).

The thematic nature of the HLTs means that each tutorial as a whole provides information and ideas which can then be drawn upon and exploited by the student in a variety of assessment activities. Assessment takes various forms. A series of hyperlinked interactive computer-based activities gives opportunities for self-assessment with general feedback. Peer and lecturer assessment strategies are employed in a non-computer setting through links to other learning activities such as lectures, seminars, practicals, workshops and discussion groups, and provide individual feedback. Amongst the assessment strategies used are several that involve the students with the continued expansion and development of the HLTs, for example a student could be required to locate an appropriate text either on a related subject or in an entirely new area which they would then analyse in order to provide a series of explanations for what they considered to be key elements of the text as well as devising a comprehension exercise with right and wrong answers. The inclusion of student-created material is an important strategy in motivating students, updating the material and making it relevant to students' needs (Landow, 1994; Harvey and Mogey, 1997).

\section{A practical application of HLTs in advanced second-language acquisition}

At the University of Bristol, four HLTs entitled Caminos a la expresividad have been developed as part of the final-year language programme from September 1999 for single and joint honours students of Spanish. They are written in Asymetrix Toolbook using the CALScribe template as a starting-point (Kitts and Whittlestone, 1998). Caminos a la expresividad centres on written texts and audio/video recordings on a variety of themes of contemporary relevance to students of Hispanic and Latin American culture. The basic aim of the tutorials is twofold. Firstly, they provide information and ideas on contemporary topics of relevance and importance to students which they can use as starting-points for discussion as they develop and refine their own ideas. To support this aim Caminos a la expresividad has lists of references for further reading, some of which are available directly from the tutorial via hyperlinks, and connections to an HLT website which provides additional ideas and links to relevant material. Secondly, the tutorials give practical assistance with language work in terms of clarifications and explanations of complex or unusual aspects of syntax and lexis and through interactive self-assessment exercises on grammar, vocabulary, comprehension and composition.

Caminos a la expresividad is being integrated fully into the final-year language curriculum through links with oral presentations and written projects. Students explore each tutorial on an open-access basis over a six-week period during which they also attend oral discussion classes and listen to, present and critique presentations by their peers. These presentations are based on tutorial topics and use texts and supplementary material to generate ideas. Some of the oral presentations will be assessed by the lecturer in addition to the written project required in each twelve-week teaching block. The students work on their own, in pairs or in small groups. Project work includes additional edited texts for inclusion in Caminos a la expresividad, 
assessed oral presentations, for example representing contrasting arguments on a topic, or written essays expressing students' own views but informed by the different opinions and ideas contained in the various texts. The best student projects will subsequently be incorporated into existing tutorials or used as the basis for new ones.

Evaluation is an essential part of the development and introduction of any new pedagogic method (Laurillard, 1993; Draper, Brown, Edgerton, Henderson, McAteer, Smith and Watt, 1994; Draper, 1997) and formative evaluation has been carried out at various points in the development of Caminos a la expresividad, from pre-program design through to target group assessment of two of the four final versions. The pilot tutorial, entitled 'La España de las Autonomías', was evaluated through observation and a user questionnaire in January/February 1998. Response to this student evaluation led to greater diversity of themes and highlighted a number of technical problems with the software which have since been resolved.

By far the most positive aspect was the overwhelming student support for the concept of the HLTs for Spanish as a new student-centred yet fully-integrated and responsive approach to final-year language teaching. Ninety-three per cent of respondents to the questionnaire enjoyed the pilot HLT and considered the Caminos a la expresividad series as a whole to be a valuable innovation to the language curriculum. A minimum of 71 per cent in each case approved of the language content, variety of exercises, planned integration and overall design of the courseware. Further user evaluation of another two of the final four Spanish HLTs was carried out in March 1999 with the current final year whose successors will be the first full users. Fortyfive students tried out the tutorials and discussed the integration plans. As far as language skills are concerned, 95 per cent agreed that the embedded metalinguistic points and exercises would help to improve their knowledge, understanding and ability to use the Spanish language, while 98 per cent of those questioned favoured the integration plans, agreeing that Caminos a la expresividad offers effective and valuable additional support to the process of oral and written expression in Spanish.

Other evaluation results are discussed below. Further evaluation will be carried out following the full integration of the tutorials into the degree programme from September 1999.

\section{Are HLTs really REALs?}

Grabinger and Dunlap (1995, p. 5) give five key aspects of the holistic constructivist approach to learning which characterize REALs. They maintain that REALs:

- promote study and investigation within authentic contexts;

- encourage the growth of student responsibility, initiative, decision-making, and intentional learning;

- cultivate collaboration among students and teachers;

- utilize dynamic, interdisciplinary, generative learning activities that promote higher-order thinking processes to help students develop rich and complex knowledge structures;

- assess student progress in content and learning-to-learn within authentic contexts using realistic tasks and performances. 
If HLTs are to be considered as REALs they should embrace these characteristics. An examination of the HLTs both in conceptual terms and in their application to second-language acquisition show that to a large extent they do indeed have these characteristics.

\section{Study within authentic contexts}

HLTs make use of authentic materials grouped together under key themes. They are rich in information that is presented in relevant, meaningful contexts by virtue both of this thematic structure and through their integration into a wider teaching programme. In terms of the Caminos a la expresividad series, this is achieved by providing texts in Spanish from authentic peninsular and Latin American sources on real-life topics of immediate relevance to today's students. They also support students in the study of the structure of the language itself in a rooted, contextual and authentic fashion.

In the March 1999 evaluation, 90 per cent of the students found the topics covered by HLTs 2 and 3 to be relevant and meaningful. While only 58 per cent agreed that a contextual approach was likely to be more effective for them than other more conventional strategies such as working through a grammar book or attending grammar classes, a large number (38 per cent) were unsure. Classroom observation and informal feedback suggests that this uncertainty was simply because the students felt unable to give a definite response until they had tried out the new approach over several weeks. Only 4 per cent felt that the new approach was unlikely to be more effective.

\section{Student responsibility and intentional learning}

Integration through assessment and the involvement of students in the continued growth and development of the HLTs motivates students, thereby promoting and encouraging study and an increase in student responsibility, initiative and decision-making. Students are also encouraged to take responsibility for their learning by the presentation of the HLTs on an open-access basis, giving the students control about how much they use them. By focusing the students' minds on the final goal of the production of an item for assessment and presenting them with varied strategies within the HLT to achieve that final goal, the tutorials encourage intentional learning, as described by Palincsar and Klenk (1992) as 'an achievement resulting from the learner's purposeful, effortful, self-regulated, and active engagement' (p. 212). In relation to Caminos a la expresividad, this applies both to the thematic work and the linguistic revision. The open presentation of the material allowing both serial and holistic approaches allows the HLTs to respond to students' endogenous learning styles and to their existing framework of knowledge.

Sixty-two per cent of students in the March evaluation agreed that having the opportunity to contribute to existing or new HLTs would encourage them to use the tutorials. Again there were very few negative responses ( 7 per cent) with the remaining 31 per cent expressing uncertainty until they had experienced the HLTs more fully. The HLT website was seen as a very positive and useful tool for the production of assignments by 97 per cent of students who considered that it would help them to develop and refine their ideas on the subjects discussed.

\section{Collaboration among students and teachers}

The collaborative process of involving students in the continued expansion and development of the HLTs is a motivating factor and a key to encouraging students to take responsibility for their learning. It gives students a share in the ownership of the learning resource and is also encouraged via additional learning activities linked to the HLTs such as non-assessed oral presentations and discussion workshops to consider ideas raised by the texts and their 
hyperlinked computer-based activities. Students have increased possibilities for collaborative work both with their peers and with their lecturers and just over 80 per cent of the students questioned in the March 1999 evaluation liked this idea.

\section{Dynamic, interdisciplinary and generative learning activities}

Both the hyperlinked and the non-computer-based activities involve students in generative learning in that, working with the ideas and concepts presented through the HLT texts, the different activities require that they 'engage in argumentation and reflection as they try to use and then refine their existing knowledge as they attempt to make sense of alternate points of view' (Grabinger and Dunlap, 1995, p. 19). The assessed work in particular involves them in relevant investigative projects which require them to develop and extend their knowledge structures, using higher-order critical and analytical skills. In Caminos a la expresividad the fact that the assessed work is in Spanish necessitates a high-level ability to use the language and this is supported by the metalinguistic aspects of the tutorials; for example, the explanations of items of syntax and lexis within the texts enable the students to observe the language in action and this in turn calls for the use of higher-order skills of analysis and synthesis to abstract the meaning behind the usage and incorporate the new structures into their own knowledge hierarchy.

While 76 per cent of students found this a more attractive approach to the learning of language than other strategies they had experienced, only the results of the first series of assessments compared to those of previous years will be able to provide a clear indication as to whether this approach is more successful at developing and extending the students' higher-order critical and analytical skills compared with previous methods employed.

\section{Assessment in authentic contexts}

Students are assessed via a variety of different tasks and projects, both formative and summative, at different levels, involving self, peer, and lecturer assessment and with feedback always provided. It is not envisaged that the Spanish HLTs will be static creations, rather the individual tutorials will be extended and new ones created with the involvement of students in all aspects and in particular utilizing material prepared by the students in the various forms of assessment, thereby rendering that assessment more meaningful and authentic.

In the March evaluation, 63 per cent of students felt that contributing directly to existing or new HLTs would give added meaning to their work and help them to feel fully involved in and responsible for their own learning. Again there were very few negative responses ( 7 per cent) with the remaining 30 per cent again expressing uncertainty until they had experienced the HLTs more fully.

\section{Conclusion}

The HLTs, both conceptually and in their application to advanced second-language acquisition, encompass the chief qualities set out in the theory of REALs, a view that is confirmed to a large extent by the evaluation carried out with final-year students in March 1999. Students are encouraged to take responsibility for their learning through generative learning activities in authentic and realistic contexts and assessed on their learning in varied ways that encourage and demonstrate higher-order thinking and a collaborative approach, in terms of both student/ student and student/lecturer interactions. 
The concept of the HLT is not limited to a language application but rather can be applied across the disciplines: the computer-based application it revolves around is easily authored and texts can be written, audio/video, pictorial or diagrammatic. Work at the University of the West of England, Bristol, on an HLT for molecular cell biology and a literary application being developed at the University of Bristol will demonstrate the interdisciplinary nature of the approach as both the programs and the integration strategies are developed and evaluated. The comprehensive integration into the degree programme of the computer application at the heart of the REAL, through a variety of complementary learning and assessment strategies, is clearly a vital factor, for without it the result would certainly be no more than useful but limited computer applications. Planned further analysis of practical applications of HLTs and detailed evaluation of the first cohort of students to graduate after the full integration of Caminos a la expresividad into the degree programme will illuminate the extent to which REALs have an effect on the final learning outcomes, both in terms of students' perceptions of their learning and their actual degree result.

\section{Acknowledgements}

The HLTs for Spanish, Caminos a la expresividad, have been supported in their development by three grants from the University of Bristol Teaching and Learning Group. The language material has been prepared by Jaine Beswick and Sally-Ann Kitts, and the language consultants for the project are Rogelio Vallejo Lozano and Carmen Brauning.

\section{References}

Desforges, C. (1997), 'A theory of complex learning', Perspectives 56, 17-22.

Draper, S. W. (1997, October), 'Observing, measuring, or evaluating courseware: a conceptual introduction', http://www.icbl.hw.ac.uk/ttdi/implementing-it/measure.htm.

Draper, S. W., Brown, M. I., Edgerton, E., Henderson, F. P., McAteer, E., Smith, E. D. and Watt, H. D. (1994), Observing and Measuring the Performance of Educational Technology, TILT Project Report no.1, Robert Clarke Centre, University of Glasgow.

Fosnot, C. T. (1996), 'Constructivism: a psychological theory of learning', in Fosnot, C. T. (ed.), Constructivism: Theory, Perspectives, and Practice, New York: Teachers College, Columbia University, 8-33.

Fox, R. (1997), 'Piaget on learning', Perspectives 56, 23-37.

Grabinger, R. S., and Dunlap, J. C. (1995), 'Rich environments for active learning: a definition', ALT $-J 3$ (2), 5-34.

Grabinger, R. S., and Dunlap, J. C. (1998, September), 'Rich environments for active learning: a definition', http://www.warwick.ac.uk/alt-E/rolling/123.

Grabinger, R. S., Dunlap, J. C. and Duffield, J. A. (1997), 'Rich environments for active learning in action: problem-based learning', ALT-J 5 (2), 3-17.

Harvey, J. and Mogey, N. (1997, October), 'Motivating students to use learning technology', http://www.icbl.hw.ac.uk/ltd/implementing-it/motif.htm. 
Jones, P., Jacobs, G. and Brown, S. (1997), 'Learning styles and CAL design: a model for the future', Active Learning 7, 9-13.

Kitts, S. A., and Whittlestone, K. D. (1998), 'CALScribe: a multimedia template ideal for CALL development', ReCALL, 10 (2) (November 1998), 4-11.

Landow, G. P. (1994), 'What's a critic to do?: critical theory in the age of hypertext', in Landow, G. P. (ed.), Hyper/Text/Theory, Baltimore: John Hopkins University Press, 1-48.

Laurillard, D. (1993), Rethinking University Teaching, London: Routledge.

Palincsar, A. S., and Klenk, L. (1992), 'Fostering literacy learning in supportive contexts', Journal of Learning Disabilities, 25 (4), 211-25.

Pask, G. (1976), 'Styles and strategies of learning', British Journal of Educational Psychology $46,128-48$.

Piaget, J. (1954), The Construction of Reality in the Child, New York: Basic Books.

Piaget, J. (1977), Equilibration of Cognitive Structures, New York: Viking.

Stoner, G. (1997, October), 'A conceptual framework for the integration of learning technology', http://www.icbl.hw.ac.uk/ltdi/implementing-it/frame.htm.

von Glasersfeld, E. (1995), Radical Constructivism: A Way of Knowing and Learning, London: Falmer. 